Article

\title{
Exploring the Multi-Function Nature of Packaging in the Food Industry
}

\author{
Ageliki Konstantoglou ${ }^{1}$, Dimitris Folinas ${ }^{2, *}$ and Thomas Fotiadis ${ }^{1}$ \\ 1 Department of Production and Management Engineering, Democritus University of Thrace, \\ 67100 Xanthi, Greece; angiekonsta@gmail.com (A.K.); dr.fotiadis.thomas@gmail.com (T.F.) \\ 2 Department of Supply Chain Management, International Hellenic University, 60100 Katerini, Greece \\ * Correspondence: dfolinas@gmail.com; Tel.: +30-6938-312-524
}

Received: 31 May 2020; Accepted: 1 July 2020; Published: 15 September 2020

\begin{abstract}
The main objective of this paper is the identification and evaluation of packaging elements by the involved managers in the food industry. Primary research data was collected using a questionnaire that was completed by marketing and logistics managers, as well as food technologists and executives assigned to environmental initiatives/practices, in the Greek food industry. The findings reveal that different managers have different perceptions regarding packaging shapes, colors, identification coding schemes and the provision of consumption ways. There are some common packaging elements that most managers agree on, which are: providing nutritional information, including marks that show compliance to environmental practices, being easy to transport and handle, and withstanding corrosion and wear. Moreover, the research confirms that: (a) Health and nutrition are two interrelated concepts that receive constant attention from the food industry, as well as from governments and consumers, and (b) The quality of a food product is inextricably linked to the quality of its packaging.
\end{abstract}

Keywords: packaging elements; food supply chain; holistic approach; survey; Greece

\section{Introduction}

The food packaging market is by far the largest application segment of the packaging industry, accounting for more than one-third of the global packaging market [1]. Packaging is one of the most crucial operations in the food industry. Almost all of the foods we trade or consume come in some sort of packaging in one form or another.

There are many different definitions for packaging. One of the most comprehensive definitions for packaging was proposed by Saghir [2], who defined packaging as a "coordinated system of preparing goods for safe, secure, efficient and effective handling, transport, distribution, storage, retailing, consumption and recovery, reuse or disposal, combined with maximizing consumer value, sales, and hence profit".

In very simple terms, packaging can be defined as all the materials of any kind used to protect, manage, deliver and present products, from raw materials to finished products, from the producer to the user or end consumer. Apart from the functional role of packaging, there is also the communicative role, simply because it becomes the voice and face of the producer's image and identity [3]. To put it another way, "packaging can be described as the least expensive form of advertising, a silent sales person, and a five-second ad."

It is obvious from the above definitions that packaging has two purposes: "to sell what it protects and to protect what it sells". This dual objective makes packaging a complex process involving two of the key operating areas of businesses: marketing and logistics management [4].

This is true, for example, for the retail sales of the food sector, where the market is highly competitive, and where producers are forced to differentiate their products from their competitors, 
at the same time that customers demand immediate delivery because these decisions are time-pressured (the buying decision is usually made within 2 to $4 \mathrm{~s}$, when the packaging is already in the consumer's hands) when choosing from among thousands of products [5]. Overall, many research initiatives highlighted the "power" of packaging as a means of promoting and influencing consumer buying behavior. Underwood, Klein and Burke [6], Underwood and Klein [7] and Limon, Kahle and Orth [8] recognize packaging as a critical communication method. Moreover, other research emphasizes the importance of packaging in product quality $[9,10]$. Consumers consider packaging as being equally important to the product brand itself. A US study conducted by the Paper and Packaging Board and IPSOS shows that 7 out of 10 (72\%) consumers agree that packaging design can influence their purchasing decision [11]. Results of the same survey have shown that $67 \%$ of consumers agree that when choosing which products to buy, these decisions are often influenced by the material of the packages [11].

In the last decade, within the business environment, many challenges related to packaging have arisen, which need to be taken into account: the aging of the global population, the trend towards smaller households, the growing demand for consumer convenience and increasing awareness on the part of consumers concerning health, as Loureiro, Gracia and Nayga [12] point out. Moreover, Marsh and Bugusu $[13,14]$ argue that there are also the trends towards on-the-go lifestyles among consumers with minimal leisure time, increasing demands for enhancing the brand and its diversification in an increasingly competitive environment, new packaging materials, the move to smaller packaging sizes, and the frequency of families eating together at the table becoming less common-this raises an awareness of environmental issues, and the need for introducing new regulatory requirements for recycling used packaging. An Environmental Protection Agency (EPA) [15] report from the US provides a generic view of the volume of packaging wastes for all business sectors. According to this report [15] "Containers and packaging make up a major portion of municipal solid waste (MSW), amounting to 80.1 million tons of generation in 2017 (29.9 percent of total generation)". In the same year in the EU-27, all packaging waste materials reached 76.9 million tons of generated waste [16].

Many researchers have identified the multifunctional nature of packaging in the food industry. Rundh [17] points out that: "in today's food market, packaging consists of three functions which include logistics, commercial and environmental functions". As Lindh et al. [18] argue, "The multifaceted nature of packaging engages many different professionals such as packaging specialists, product developers, logisticians and marketing experts in the packaging development process". Singh, Wani and Langowski [19] examine practical solutions and innovative packaging materials for food products in view of packaging integrity, shelf life of products and conformity with current regulations. Moreover, today more than ever, companies have come to realize that packaging can certainly affect consumers' decision-making as Silayoi and Speece [20] point out, as well as to improve the performance of a business in terms of storage and transport by standardizing their respective logistics activities, at the same time as minimizing their operational costs [21-23] and providing the market with a pro-environmental image and a high sense of social responsibility [24,25].

This study appreciates the multidisciplinary nature of food packaging-aligned with the aforementioned research initiatives-and proposes a framework that encompasses the required elements of marketing and logistics managers, food technologists and executives responsible for environmental issues, so that food manufacturers can take into account those elements that are highly appreciated by all of the aforementioned executives.

The different views on the significance of packaging elements have been provided by business executives in the food supply chain and businesses/chain members. The main research questions of this study are:

1. What are the elements of packaging that business executives recognize as being critical in the food supply chain? 
2. How (and if) are the views of executives differentiated concerning marketing, logistics, food technology and environmentally-friendly initiatives, with regard to the importance of the elements involved in food packaging? and

3. Which manager is considered by the various executives of the food industry as the person who will make the final decision on what elements should be included in the packaging of the products offered?

The paper is organized as follows: The next section recognizes the multidisciplinary character of packaging in the food sector. Then, the key elements of packaging related to marketing, logistics, food technology and environmental initiatives are identified and categorized. Based on these elements, the primary research is focused on the food sector. The sample included responses from manufacturers in the packaged food market of Greece. The fourth section presents and discusses the findings. Finally, conclusions and recommendations are provided for future research.

\section{Packaging Dimensions in the Food Sector}

The importance of packaging in the food industry is demonstrated by its multidisciplinary and multifunctional nature. During the designing of a form of food packaging, executives from different functional areas are involved. This is because packaging serves important as well as different roles/goals:

- Physical protection of products against damage, shock, vibration, temperature, heat, moisture, etc. during their handling and storage processes,

- Consumer health protection against microbial and bacterial contamination/spoilage, as well as climatic hazards of the products, keeping them healthy, clean, fresh, sterile and safe for their intended shelf life,

- Unitization of foods, sorted from one type of packaging to a bigger unit load, in order to facilitate their movement within the food supply chain. Primary packages (items) are grouped into secondary packaging units (e.g., cartons) and these in turn are grouped into tertiary packages transport packs, for example pallets.

- Provision of information to consumers on topics concerning the use, consumption, storage, and recycling of packaged foods.

- Attracting consumers to buy the product.

In addition, the latest developments in changes to consumers' dietary habits and an increased environmentally-friendly conscience among them render as necessary a more holistic approach to packaging, which will determine the packaging elements by taking into account factors such as those relating to the following [3]:

- Marketing: Silayoi and Speece [26] support the view that well-designed packaging attracts the attention of the consumer and is therefore an important tool in product differentiation. Furthermore, Wells et al. [27] and Keller [28] conclude that packaging can also serve as an effective communication tool. Many researchers have attempted to identify the elements of packaging that influence the buying behavior of consumers. Wells, Farley and Armstrong [27], as well as Butkeviciene, Stravinskiene and Rutelione [29] identify the factors that influence consumers' purchase decisions. Vila and Ampuero [30] who examined the associations between different positioning strategies and the different graphic design variables and based on these associations, Simms and Trott [31] propose new product opportunities.

- Logistics Management: This is related to guidelines on how to optimize material flow and handling, warehousing functions, facilitation of transportation and distribution, the protection of both the products and the environment as well as the provision of information regarding the conditions and the placement of the product. Bowersox and Closs [21] identify the operational areas where the packaging positively influences the cost, monitoring or reducing the following: management 
(control) of inventory, product identification (of the packaging), handling of materials, picking and lead-time. Moreover, it contributes to increasing supply chain efficiency by facilitating procedural actions and reducing the respective errors. Lambert, Stock and Ellram [22] studied the positive influence of packaging on basic logistics operations, such as having more information available on the packaging, increased protection from the packaging, increased standardization and optimization in the use of available space.

- Food technology: This relates to information on the food/product, such as, for example, its nutrients, the existence of allergens, preparation/cooking instructions, information relating to production and best-by dates and whether the product is organic or certified. Packaging aims to preserve the quality and freshness of the food by maintaining its sensory characteristics, such as texture, color and flavor, as well as the nutritional value of high mineral and vitamin levels, and low chemical preservatives content. It informs the customer by describing the product and perhaps describing how to handle the package and use the product $[32,33]$.

- Environmental information: This is principally aimed at reducing the environmental impact, reducing energy consumption, informing consumers about the option to reuse or recycle the packaging, etc. [34]. Of course, efforts to record the food product's environmental footprint are not new, as from time to time various initiatives and programs have been designed and implemented, such as eco-friendly product labels, organic products and energy efficiency labels [35-37]. Recyclability of packaging in the food industry is a crucial step towards a circular economy. According to the Circular Economy Package proposed by European Commission, the target for recycling of packaging waste is $60 \%$ by $2020,70 \%$ by 2025 and $80 \%$ by 2030 [38]. Other stated targets include $90 \%$ recycling for paper and $60 \%$ for packaging made of plastic by 2025 , as well as $80 \%$ for packaging made of wood by 2030 [39]. Also for 2030: $90 \%$ recycling of all packaging consisting of iron, aluminum or glass.

\section{Elements of Packaging in the Food Sector}

Many researchers have tried to identify the key elements of packaging in general, and especially in the food industry. In simple terms, the elements included here are those factors/components that have been identified as serving the requirements of the four functional areas. Items falling within the current legislative, regulatory and institutional framework have been excluded.

The in force legislative framework, which applies to all countries of the European Union (EU), includes general rules on food labeling (horizontal legislation), and rules for specific categories of food, e.g., olive oil and chocolate (vertical legislation). In particular, the new EU legislation is concerned with the general rules involved in the labeling of foodstuffs in terms of the provision of food information to consumers [40]. It has been mandatory since 13 December 2014 and consolidates two Directives (2000/13/EC and 90/496/EEC) into legislation, with Regulation (EU) No 1169/2011 laying down the general principles, requirements and obligations regarding food information, particularly general and nutritional labeling. It is understood that either these elements affect consumer-purchasing decisions, as the studies by Prendergast and Marr [41] as well as Rettie and Brewer [42] or Esiti et al. [43] pointed out; these are the main reasons why operations managers and logistics managers use them to choose the best packaging for their products.

Moreover, many research initiatives examined the application of environmentally friendly approaches in the design of food packages. Guillard et al. [44] examine solutions to address pressing international stakes in terms of food and plastic waste reduction and end-of-life issues of persistent materials. Cabot et al. [45] propose a smart interconnected container that is able to detect the ethylene emitted by climacteric fruit, thereby minimizing food wastage. Moreover, Molina-Besch, Wikström and Williams [46] as well as Wikström and Williams [47] proposed Life Cycle Assessment tools and models to design new packages for food products.

This also applies with regard to food technologists, who propose new package materials; such as antimicrobial materials suggested by Appendini and Hotchkiss [32] or bio-nanocomposite materials 
introduced by Sorrentino, Gorrasi and Vittoria [33]. Other research proposes instructions on how to handle and use the package of products such as Paine [48] and describe different implications of an efficient product packaging system for successful management of logistics operations [49,50].

Based on the above studies, as well as the findings of Konstantoglou et al. [51-53] concerning research initiatives concentrated in the food industry, 43 elements are extracted and classified into four categories (Informational, Operational, Physical and Visual elements), as presented in Table 1.

Table 1. Categorization of packaging elements for food products [51-53].

\begin{tabular}{|c|c|}
\hline Category & Elements \\
\hline $\begin{array}{l}\text { Provides information about the company, information about } \\
\text { the product (ingredients), nutritional information, production } \\
\text { or remaking techniques, quality standard marks, compliance } \\
\text { with environmental practices, data that support traceability, lot } \\
\text { number, product identification coding schemes such as } \\
\text { barcode, QR-code, etc., marks for flammable/hazardous } \\
\text { materials, proposed ways of consumption, storage conditions } \\
\text { and brand elements (logos, slogans, symbols, etc.). }\end{array}$ & $\begin{array}{l}\text { 1. Provides nutrition information } \\
\text { 2. Reports production or reproduction techniques } \\
\text { 3. Includes quality standard marks } \\
\text { 4. Includes marks that show compliance to environmental practices } \\
\text { 5. Includes data that support traceability } \\
\text { 6. Includes product identification coding schemes such as barcodes, } \\
\text { QR-codes, etc. } \\
\text { 7. Includes marks for flammable/hazardous materials, storage } \\
\text { 8. Provides proposed ways of consumption } \\
\text { 9. Suggests recipes for this product } \\
\text { 10. Indicates country of origin and secondary materials } \\
\text { 11. Shows product temperature at any given time } \\
\text { 12. Designates a protected origin name }\end{array}$ \\
\hline $\begin{array}{l}\text { Operational elements } \\
\text { Supports (physical) operational elements, such as: protection } \\
\text { of the product from theft, protection of the product from } \\
\text { moisture, ease of placing/mounting the product on the shelf, } \\
\text { does not expose the product to light, allows visual contact with } \\
\text { part of the product, ease of transportation and handling, while } \\
\text { also permitting packaging in larger packages/logistics units } \\
\text { (cartons, pallets, etc.). }\end{array}$ & $\begin{array}{l}\text { 13. Protects the product from theft } \\
\text { 14. Protects the product from moisture } \\
\text { 15. Can easily be mounted on the shelf } \\
\text { 16. Does not expose the product to light } \\
\text { 17. Allows visual contact with part of the product } \\
\text { 18. Can easily be transported and handled } \\
\text { 19. Allows packaging in larger packages/logistics units (carton, } \\
\text { 20. Is ready to cook } \\
\text { 21. Increases the product life } \\
\text { 22. Has a smart label } \\
\text { 23. The shape of the package describes the product content } \\
\text { 24. Does not expose light to solar radiation }\end{array}$ \\
\hline Physical elements & 25. Has a marginally bigger size than the product size \\
\hline $\begin{array}{l}\text { Refers to physical characteristics such as: size (marginally } \\
\text { bigger than the product size), volume (marginally bigger than } \\
\text { the product volume), shape (following common/typical shapes } \\
\text { e.g., square, rectangle, triangle, circle), material/components } \\
\text { (e.g., made of durable materials, materials that add prestige to } \\
\text { the product, materials that are environmentally friendly, } \\
\text { materials that can be reused and materials that allow for } \\
\text { elongation), being waterproof, withstanding mechanical stress, } \\
\text { corrosion and wear, cheap (a low price of production or } \\
\text { recycling) and having a light/low weight. }\end{array}$ & $\begin{array}{l}\text { 26. Has a marginally bigger volume than the product's volume } \\
\text { 27. Follows common/typical shapes (e.g., square, rectangle, } \\
\text { triangle, circle) } \\
\text { 28. Is made of durable materials } \\
\text { 29. Is waterproof } \\
\text { 30. Withstands mechanical stress } \\
\text { 31. Withstands corrosion and wear } \\
\text { 32. Is light/has low weight } \\
\text { 33. Is produced by material/components (e.g., is made of durable } \\
\text { materials that add prestige to the product) } \\
\text { 34. Is produced by materials that are environmentally friendly } \\
\text { 35. Is produced by materials that can be reused and materials that } \\
\text { 36. Is cheap (a low price of production or recycling) } \\
\text { 37. Does not allow odors to leak } \\
\text { 38. Is made of recycled materials }\end{array}$ \\
\hline $\begin{array}{l}\text { Visual elements } \\
\text { Refers to: vivid (strong) colors, only one color (monochrome), } \\
\text { only a white color (background), many blank parts and/or } \\
\text { product photography/image/graphics. }\end{array}$ & $\begin{array}{l}\text { 39. Has vivid/strong colors } \\
\text { 40. Has only one color (monochrome) } \\
\text { 41. Has only a white color } \\
\text { 42. Has many blank parts (or has only a white color as a background) } \\
\text { 43. Has a picture }\end{array}$ \\
\hline
\end{tabular}

\section{Research Method}

The main objective of this research is to examine food-packaging elements from different business executives' points of view. There are three research questions: 
1. Which are the elements of packaging that business executives recognize as critical in the food supply chain?

2. How (and if) are the views of executives differentiated concerning marketing, logistics, food technology and environmentally-friendly initiatives, with regard to the importance of elements involved in food packaging?

3. Which manager is considered by the various executives of the food industry as the person who will make the final decision on what elements should be included in the packaging of the products?

The research was focused on the food sector and the sample included manufacturers in the packaged food market in Greece. Primary data were collected through a questionnaire that included four sections:

- The first section asked for information about the company,

- The second section tried to sketch the profile of the manager's main role (marketing, logistics, food technology, or environmental) and

- The third section aimed to assess the significance of the packaging elements using a five-point Likert scale (from "1: Not significant" to "5: Very significant"). The 43 packaging elements that were provided at the Table 1 (Categorization of packaging elements for food products) are used.

- The fourth part included only two questions. The first question asked executives in the food industry to suggest the specific executive who would decide on which elements should be included/taken into account in the design of the packaging. The second question gave the opportunity to managers to suggest which other executive they would want to work with (each respondent had to nominate only one).

Before the questionnaire was administered, it was pilot-tested using the method of content validity with ten managers, in order to check the appropriateness of the elements and to ensure that there was a clear understanding of the questions confirmed in the questionnaire sample. In addition, in order to assess the reliability of the questionnaire, Cronbach's alpha was estimated. For this purpose, a prototype of 60 questionnaires from the pilot test were taken. The results (Cronbach alpha $=0.926$ ) show that the questionnaire used in this study has a high reliability for achieving its main objectives. The data collected were analyzed using SPSS version 23.0. The analysis included descriptive and inferential analysis.

Over a thousand (1100) questionnaires were distributed among companies in the targeted sector; a final count of 390 questionnaires have been retuned completed and were used in this study. 131 (33.6\%) were answered by marketing/sales managers, 87 (22.3\%) logistics/operations managers, 112 (28.7\%) food technology scientists working in the production sector and $60(15.4 \%)$ managers assigned to environmental practices. The sample can be considered as being representative since it consists of companies that first are located in the main industrial areas in Greece (such as in the areas of Athens, Thessaloniki, Larisa and Ioannina), and second because that 7 out of 10 of them are SMEs (specifically, $72 \%$ of the respondents were working in SMEs with only $28 \%$ working in big companies). According to the annual sectorial report in Greek food and beverages sector conducted by PWC [54], this follows the typical profile of companies in the targeted sector.

Most of the respondents have many years of experience in the sector and a high level of education. Specifically, 138 of the executive managers $(35.4 \%)$ who answered the questionnaire had completed secondary education, while the remaining 252 (64.6\%) had an advanced education. The mean number of years of the respondents on the job was 10.6 years with a standard deviation of 6.6 years. Prior service was significantly different between different specializations $(\mathrm{F}(3382)=4786, p=0.003)$. The least experienced group was the environmental managers $(\mathrm{M}=8.6, \mathrm{SD}=7,95 \%$ C.I. $6.8-10.4$ years) (Figure 1). In contrast, food technologists had the longest prior experience ( $\mathrm{M}=12.2, \mathrm{SD}=6.6,95 \%$ C.I. 10.9-13.4 years). Concerning educational level, there was no significant difference in the experience between the two educational level groups (Secondary 11.3 years, vs. Advanced education: 10.2 years, $p=0.097)$. 


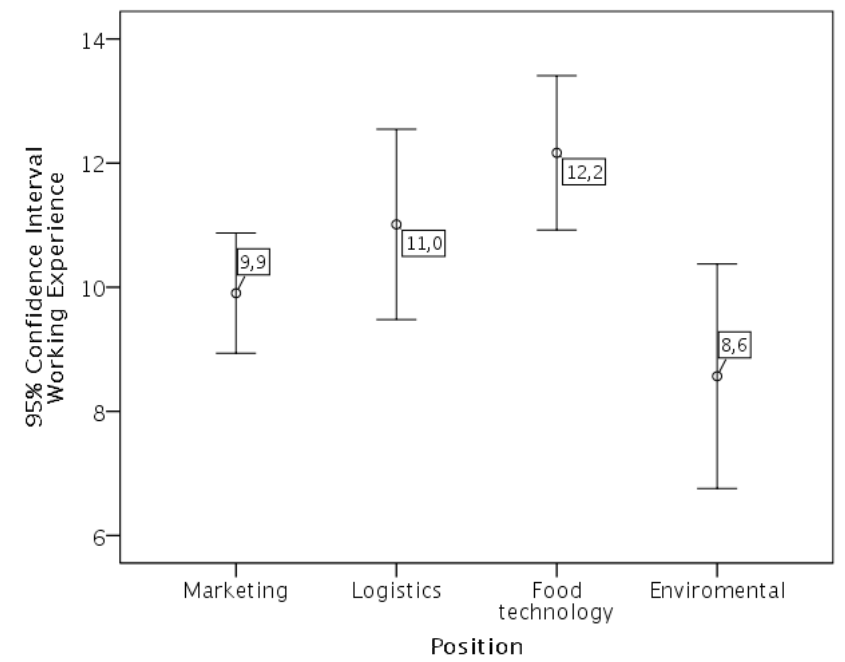

Figure 1. Relationship between professional position and years of service.

\section{Findings}

The section presents the findings of the study and it is organized based on the three research questions provided in the previous section.

\subsection{Elements of Packaging that Managers Recognize as Critical in the Food Supply Chain}

Regarding which elements executives perceive to be the most important per group of elements (the first research question), Table 2 below presents the average responses to 43 questions (where the bold statements represent the executives with an average greater than 4.00). Table 2 presents the means and standard deviations for all the packaging elements.

In general, most elements of the informational and operational groups are considered by executives to be more important, while those of the visual group are less important. The averages of the items in these groups are higher than the overall average compared to those in the visual group. This is probably due to the views of the executives on logistics, food technology and environmental practices. It may also be due to the question concerning: "Which are the main objectives concerning which elements are taken into consideration in packaging design - presentation and aesthetics, or security and information?" The responses of the executives seem to converge towards the latter.

Table 2. Categorization of packaging elements per group.

\begin{tabular}{lllcc}
\hline & N. & Element & Mean & Std. Deviation \\
\hline Informational & & & & \\
& q8 & Includes quality standard marks & 4.25 & 0.944 \\
& q6 & Provides nutritional information & 4.11 & 1.046 \\
& q12 & Includes marks for flammable/hazardous materials & 3.98 & 1.101 \\
& q9 & Includes marks for compliance to environmental practices & 3.98 & 1.055 \\
& q11 & Includes product identification coding schemes & 3.93 & 1.176 \\
& q10 & Includes data that support traceability & 3.91 & 1.114 \\
& q35 & Indicates country of origin and secondary materials & 3.86 & 1.202 \\
& q39 & Designates a protected origin name & 3.81 & 1.110 \\
& q7 & Reports production or reproduction techniques & 3.70 & 1.176 \\
& q13 & Provides proposed ways of consumption & 3.53 & 1.149 \\
& q33 & Suggests recipes for this product & 3.42 & 1.181 \\
& & & & \\
& q22 & Protects the product from moisture & 4.06 & 0.999 \\
& q24 & Does not expose the product to light & 3.98 & 1.023 \\
& q30 & Can easily be transported and handled & 3.97 & 0.973 \\
& q41 & Does not expose light to solar radiation & 3.89 & 1.065 \\
\hline
\end{tabular}


Table 2. Cont.

\begin{tabular}{lllcc}
\hline & N. & Element & Mean & Std. Deviation \\
\hline & q31 & Allows packaging in larger packages/logistics units & 3.81 & 1.087 \\
q23 & Can easily be mounted on the shelf & 3.78 & 1.108 \\
q38 & Smart label & 3.62 & 1.174 \\
& q25 & Allows visual contact with part of the product & 3.60 & 1.216 \\
q40 & The shape of the package & 3.52 & 1.186 \\
q36 & Shows the product temperature at any time & 3.48 & 1.171 \\
& q37 & Increases product life & 3.44 & 1.152 \\
q34 & Is ready to cook & 3.34 & 1.160 \\
q21 & Protects the product from theft & 3.24 & 1.287 \\
& & & \\
& q42 & Does not allow odors to leak & 4.02 & 1.077 \\
q20 & Withstands corrosion and wear & 4.01 & 1.102 \\
q28 & Is produced by environmentally-friendly materials & 3.94 & 1.093 \\
q19 & Withstands mechanical stress & 3.83 & 1.125 \\
q18 & Is waterproof & 3.79 & 1.090 \\
q17 & Is made of durable materials & 3.78 & 1.011 \\
q43 & Is made of recycled materials & 3.75 & 1.147 \\
q32 & Is cheap (low price of production or recycling) & 3.72 & 1.091 \\
q29 & Is produced by materials that can be reused & 3.71 & 1.173 \\
q27 & Is produced by materials/components & 3.64 & 1.102 \\
q14 & Has a size marginally bigger than the product's size & 3.32 & 1.162 \\
q26 & Is light/has a low weight & 3.22 & 1.047 \\
q15 & Has volume marginally bigger than the product's volume & 3.19 & 1.169 \\
q16 & Follows the common/typical shapes & 2.98 & 1.242 \\
& & & \\
q5 & Has a picture & 3.14 & 1.177 \\
q1 & Has vivid/strong colors & 2.69 & 1.026 \\
q4 & Has many blank parts & 2.35 & 1.069 \\
q3 & Has only a white color & 2.17 & 0.902 \\
q2 & Has only one color (monochrome) & 1.94 & 0.855 \\
\hline
\end{tabular}

5.2. Differences and Similarities between Managers, with Regard to the Elements Involved in Food Packaging

The findings reveal that different managers have different perceptions regarding packaging in regards to shape, colors, identification coding schemes and the provision of consumption ways. Table 3 below presents the differences between the responses per category of the different specializations of the executives.

Packaging in the food supply chain can only be approached holistically, that is, when emphasis is placed on its multidisciplinary nature [2,55]. According to the findings, for some questions (concerning packaging elements), all executives seem to agree with them, in terms of their high or low importance value. These are presented in different colors (blue and yellow, respectively). Specifically, there is agreement on the high importance of the following:

- q6 Provides nutritional information.

- $\quad$ q9 Includes marks that show compliance to environmental practices.

- $\quad$ q30 Can easily be transported and handled.

- $\quad$ q20 Withstands corrosion and wear.

And there is agreement that the following have a low importance value:

- $\quad$ q2 Has only one color (monochrome).

- $\quad$ q3 Has only a white color.

- $\quad$ q4 Has many blank parts (or has only white color as a background).

- $\quad$ q5 Has a picture.

- $\quad$ q14 Has a size marginally bigger than the product's size.

- $\quad$ q15 Has a volume marginally bigger than the product's volume.

- $\quad$ q26 Is light/has a low weight. 
- q33 Suggests recipes for this product.

- $\quad$ q34 Is ready to cook.

- $\quad$ q35 Indicates the country of origin and secondary materials.

- $\mathrm{q} 36$ Shows the product temperature at any time.

- $\quad$ q37 Increases the product life.

- q38 Has a smart label.

- $\mathrm{q} 40$ The shape of the package describes the product content.

Table 3. Synopsis of the responses (M(SD)) for each executive category.

\begin{tabular}{|c|c|c|c|c|c|c|c|}
\hline \multicolumn{8}{|c|}{ Informational } \\
\hline Group & Question & Mean (S.Dev.) & Marketing & Logistics & Food Tech. & Environment & $\mathrm{P}^{(1)}$ \\
\hline inf.q1 & q.6 & $4.1(1)$ & $4.1(1.1)$ & $4.2(0.9)$ & $4.1(1.1)$ & $4.1(1)$ & 0.836 \\
\hline inf.q2 & $\mathrm{q} .7$ & $3.7(1.2)$ & $3.7(1.2)$ & $3.5(1.2)$ & $3.9(1.1)$ & $3.6(1.2)$ & 0.036 \\
\hline inf.q3 & q. 9 & $4.2(0.9)$ & $4.1(1)$ & $4.4(0.8)$ & $4.3(1)$ & $4.3(0.9)$ & 0.314 \\
\hline inf.q4 & g.10 & $4(1.1)$ & $3.8(1.1)$ & $4.1(1)$ & $4.1(1.1)$ & $3.9(0.9)$ & 0.138 \\
\hline inf.q5 & q.11 & $3.9(1.1)$ & $3.6(1.2)$ & $4.2(0.9)$ & $4(1.1)$ & $4.1(1)$ & 0.002 \\
\hline inf.q6 & q.12 & $3.9(1.2)$ & $3.5(1.2)$ & $4.1(1)$ & $4.1(1.2)$ & $4.2(1)$ & 0.000 \\
\hline inf.q7 & q.13 & $4(1.1)$ & $3.7(1.2)$ & $4.2(1.1)$ & $4.0(1.0)$ & $4.2(0.9)$ & 0.005 \\
\hline inf.q8 & q.33 & $3.5(1.1)$ & $3.5(1.1)$ & $3.5(1.0)$ & $3.8(1.1)$ & $3.2(1.4)$ & 0.012 \\
\hline inf.q9 & $\mathrm{q} .35$ & $3.4(1.2)$ & $3.1(1.2)$ & $3.5(1.1)$ & $3.7(1.2)$ & $3.6(1)$ & 0.000 \\
\hline inf.q10 & q.39 & $3.9(1.2)$ & $3.7(1.2)$ & $3.9(1.3)$ & $3.9(1.2)$ & $4(1.1)$ & 0.214 \\
\hline inf.q11 & q.36 & $3.8(1.1)$ & $3.7(1.2)$ & $3.8(1.1)$ & $4(1.1)$ & $3.7(0.9)$ & 0.060 \\
\hline \multicolumn{8}{|c|}{ Operational } \\
\hline Group & Question & Mean (S.Dev) & Marketing & Logistics & Food Tech. & Environment & $\mathrm{P}^{(1)}$ \\
\hline oper.q1 & q.21 & $3.2(1.3)$ & $3.3(1.3)$ & $3.3(1.2)$ & $3.4(1.3)$ & $2.7(1.3)$ & 0.005 \\
\hline oper.q2 & $\mathrm{q} \cdot 22$ & $4.1(1)$ & $4.1(0.9)$ & $4.1(0.9)$ & $4.1(1)$ & $3.7(1.2)$ & 0.037 \\
\hline oper.q3 & $\mathrm{q} .23$ & $3.8(1.1)$ & $3.7(1.1)$ & $4.0(1.0)$ & $3.9(1)$ & $3.6(1.2)$ & 0.047 \\
\hline oper.q4 & $\mathrm{q} .24$ & $4(1)$ & $3.9(1)$ & $4.2(1.0)$ & $4.1(0.9)$ & $3.6(1.1)$ & 0.002 \\
\hline oper.q5 & q.25 & $3.6(1.2)$ & 3.7 (1.1) & $3.6(1.4)$ & $3.6(1.2)$ & $3.4(1.1)$ & 0.633 \\
\hline oper.q6 & q.30 & $4(1)$ & $3.8(1.1)$ & $4.1(0.8)$ & $4(1)$ & $4.1(0.9)$ & 0.045 \\
\hline oper.q7 & q.31 & $3.8(1.1)$ & $3.6(1.1)$ & $4.0(1.0)$ & $3.9(1)$ & $3.9(1.2)$ & 0.025 \\
\hline oper.q8 & q.34 & $3.3(1.2)$ & $3.4(1.2)$ & $3.3(1.1)$ & $3.5(1.1)$ & $2.9(1.2)$ & 0.004 \\
\hline oper.q9 & q.36 & $3.5(1.2)$ & $3.3(1.2)$ & $3.6(1.2)$ & 3.7 (1.1) & $3.3(1)$ & 0.011 \\
\hline oper.q10 & q.37 & $3.4(1.2)$ & $3.3(1.2)$ & $3.3(1.1)$ & $3.8(1.2)$ & $3.3(1)$ & 0.010 \\
\hline oper.q11 & $\mathrm{q} .38$ & $3.6(1.2)$ & $3.6(1.2)$ & $3.8(1.2)$ & $3.5(1.2)$ & $3.5(1)$ & 0.308 \\
\hline oper.q12 & q. 40 & $3.5(1.2)$ & $3.3(1.2)$ & $3.6(1.1)$ & $3.5(1.3)$ & $4(0.9)$ & 0.000 \\
\hline oper.q13 & q.41 & $3.9(1.1)$ & $3.6(1.1)$ & $4.1(1.1)$ & $4.2(1)$ & $3.7(0.9)$ & 0.000 \\
\hline \multicolumn{8}{|l|}{ Physical } \\
\hline Group & Question & Mean (S.Dev) & Marketing & Logistics & Food Tech. & Environment & $P^{(1)}$ \\
\hline phys.q1 & $\mathrm{q} .14$ & $3.3(1.2)$ & $3.1(1.1)$ & $3.5(1.2)$ & $3.5(1.1)$ & $3.4(1.3)$ & 0.027 \\
\hline phys.q2 & $\mathrm{q} .15$ & $3.2(1.2)$ & $3(1.2)$ & $3.3(1.2)$ & $3.3(1.1)$ & $3.1(1.2)$ & 0.062 \\
\hline phys.q3 & q.16 & $3(1.2)$ & $2.7(1.1)$ & $3.4(1.2)$ & $3(1.3)$ & $3(1.3)$ & 0.005 \\
\hline phys.q4 & q.17 & $3.8(1)$ & $3.7(1)$ & $3.8(1)$ & $3.8(1)$ & $3.9(1)$ & 0.771 \\
\hline phys.q5 & q.18 & $3.8(1.1)$ & $3.7(1.1)$ & $3.9(1)$ & $4(1)$ & $3.6(1.1)$ & 0.060 \\
\hline phys.q6 & q.19 & $3.8(1.1)$ & $3.8(1.1)$ & $3.9(1.1)$ & $3.9(1.1)$ & $3.7(1.2)$ & 0.506 \\
\hline phys.q7 & $\mathrm{q} .20$ & $4(1.1)$ & $3.9(1.1)$ & $4.2(1)$ & $3.9(1.2)$ & $4.1(1.1)$ & 0.202 \\
\hline phys.q8 & q.26 & $3.2(1)$ & $3.1(1.1)$ & $3.4(1)$ & $3.3(1)$ & $3.1(0.9)$ & 0.076 \\
\hline phys.q9 & q.27 & $3.6(1.1)$ & $3.7(1.1)$ & $3.6(1.1)$ & $3.9(1.1)$ & $3.2(1)$ & 0.000 \\
\hline phys.q10 & q. 28 & $3.9(1.1)$ & $3.8(1.2)$ & $4.1(0.8)$ & $4.1(1.2)$ & $3.7(1.1)$ & 0.019 \\
\hline phys.q11 & q.29 & $3.7(1.2)$ & $3.7(1.2)$ & $3.7(1)$ & $3.9(1.2)$ & $3.4(1.3)$ & 0.099 \\
\hline phys.q12 & q.32 & $3.7(1.1)$ & $3.7(1.1)$ & $3.9(1)$ & $3.7(1.1)$ & $3.5(1.2)$ & 0.167 \\
\hline phys.q13 & q. 42 & $4(1.1)$ & $3.8(1.1)$ & $4.1(0.9)$ & $4.2(1.1)$ & $3.8(1.1)$ & 0.013 \\
\hline phys.q14 & $\mathrm{q} .43$ & $3.7(1.1)$ & $3.6(1.2)$ & $4(1)$ & $3.7(1.2)$ & $3.7(1)$ & 0.035 \\
\hline \multicolumn{8}{|l|}{ Visual } \\
\hline Group & Question & Mean (S.Dev) & Marketing & Logistics & Food Tech. & Environment & $P^{(1)}$ \\
\hline vis.q1 & q.1 & $2.7(1)$ & $2.8(1)$ & $2.7(1)$ & $2.8(1)$ & $2.2(0.9)$ & 0.001 \\
\hline vis.q2 & $\mathrm{q} .2$ & $1.9(0.9)$ & $1.9(0.7)$ & $2(1)$ & $1.9(0.9)$ & $1.9(0.9)$ & 0.664 \\
\hline vis.q3 & q.3 & $2.2(0.9)$ & $2.2(0.9)$ & $2.1(0.8)$ & $2.3(0.9)$ & $2.1(0.9)$ & 0.347 \\
\hline vis.q4 & q. 4 & $2.3(1.1)$ & $2.4(1)$ & $2.2(1.1)$ & $2.4(1.1)$ & $2.3(1)$ & 0.282 \\
\hline vis.q5 & q.5 & $3.1(1.2)$ & $3.3(1.1)$ & $2.8(1.2)$ & $3.3(1.3)$ & $3.1(1)$ & 0.018 \\
\hline
\end{tabular}

(1) Significance of differences between consumers and executives (managers) $(\mathrm{a}=0.01) .{ }^{(2)}$ Significance of differences among manager groups $(\mathrm{a}=0.01)$. 
For several questions, there were also individual variations among the answers for the different specializations of the executives:

- $\quad$ q1 Has vivid/strong colors.

- $\quad$ q11 Includes product identification coding schemes.

- $\quad$ q12 Includes marks for flammable/hazardous materials, etc.

- $\quad$ 13 Provides proposed ways of consumption.

- $\quad$ q21 Protects the product from theft.

- $\quad$ q24 Does not expose the product to light.

- $\quad$ q27 Is produced by materials/components.

- $\quad$ 16 Follows the common/typical shapes.

- $\quad$ q34 Is ready to cook.

- $\quad$ q35 Indicates the country of origin and secondary materials.

- $\mathrm{q} 40$ The shape of the package describes the product content.

- $\mathrm{q} 41$ Does not expose light to solar radiation.

\subsection{Decision Making on Packaging Elements}

The last question asked executives in the food industry to suggest the specific executive (i.e., the particular position of the executive) who would ultimately decide on which elements should be included/taken into account in the design of the packaging. The results highlighted the Marketing Director, with 146 (37.4\%) responses, who is traditionally the final decision-maker, as the most appropriate production executive of the company to make that decision.

The high percentage of food technologists (a total of 120, or 30.8\%) as well as those responsible for logistics (a total of 93 , or $23.8 \%$ ), are impressive. It is not surprising that a low percentage of executives (a total of 31, or $8 \%$ ), preferred the implementation of environmentally-friendly initiatives in packaging. As expected, there was a statistically significant correlation between the respondent's position and who would actually make the final decision on the packaging (Pearson Chi-Square $=68,848, \mathrm{df}=12$, $p=0.0001)$.

Executives were also given the opportunity to suggest which other executive they would want to work with. Marketing executives mainly suggested the logistics executives and the food technologists at about the same rate. Similarly, logistics executives suggested collaborating with marketing executives and food technologists. Food technologists who prefer to work with marketing executives numbered twice as many as logistics executives. The finding that the overwhelming majority of executives $(84 \%)$ believe that all executives should be involved in the packaging decision was a rather significant finding. Logistics executives are slightly differentiated, in that these believe that the decision should be made in collaboration with marketing executives and food technologists.

\section{Conclusions}

Packaging is a core business function. Marketers believe that it is the fifth " $\mathrm{P}$ " of marketing. Logistics officers plan the warehousing and transportation systems (means) according to the main parameters/dimensions of the packaging. Environmental specialists see packaging as an excellent area to apply all available green practices and technologies, while food scientists argue that it plays a critical role in the information dissemination, habits and culture of consumers.

This study aims to identify and evaluate packaging elements in the food industry from a holistic point of view. Findings of the study justify the results of many research initiatives that the importance of packaging in the food industry lies in its multifunctional nature. Packaging elements of food products can come from studying the contribution of different research disciplines and functional areas: marketing, logistics, food technologies and the environment. 


\subsection{Elements of Packaging that Managers Recognize as Critical in the Food Supply Chain}

A number of 43 elements have been identified and classified for the purpose of the study as follows:

- Informational elements, that provide information about the company, product, production process, etc. and data that support traceability, logistics processes, etc.

- Operational elements that contribute to the protection of the product from theft, moisture, light, etc. allow visual contact with part of the product, ease of transportation and handling, while also permitting packaging in larger packages/logistics unit loads.

- Physical elements that refer to physical characteristics such as size, volume, shape, materials, price, weight, etc.

- Visual elements, referring to colors, blank parts and product photography/image/graphics.

\subsection{Differences and Similarities between Managers, with Regard to the Elements Involved in Food Packaging}

Furthermore, the findings reveal that different packaging elements have different functional implications on key roles in the targeted industry.

Perspectives were differentiated in the following way:

- Marketing executives place importance on the following element that logistics executives and food technologists consider as inferior: q16 (Follows the common/typical shapes); whereas for q13 (Provides proposed ways of consumption), these share a common view with food technologists and executives involved in environmentally-friendly initiatives.

- Logistics executives and food technologists have a common appreciation of q41 (Does not expose light to solar radiation).

- Logistics executives share perspectives for: q11 (Includes product identification coding schemes), q12 (Includes marks for flammable/hazardous materials, etc.), and q35 (Indicates country of origin and secondary materials) with food technologists and executives involved in environmentally-friendly practices.

- The following items: q27 (Is produced by materials/components, e.g., is made of durable materials that add prestige to the product), q24 (Does not expose the product to light), q34 (Is ready to cook), q1 (Has vivid/strong colors) and q21 (Protects the product from theft) are considered to be important by marketing executives, logistics executives and food technologists, but not by executives involved in environmentally-friendly practices, while the opposite is true for q40 (The shape of the package describes the product content).

Nevertheless, there are some common packaging elements that most managers agree on, which are: providing nutritional information, including marks that show compliance to environmental practices, being easy to transport and handle and withstanding corrosion and wear. This is interesting because each idea conceptually belongs to the four different functional areas.

Of great interest was the finding in the research concerning the focus of the executives among the elements that support packaging for the protection and safety of the products. In other words, the research confirms that: (a) Health and nutrition are two interrelated concepts that receive constant attention from the food industry, as well as from governments and consumers; and (b) The quality of a food product is inextricably linked to the quality of its packaging.

\subsection{Decision Making on Packaging Elements}

The results highlighted the Marketing Director, who is traditionally the final decision-maker, as the most appropriate production executive of the company in the food industry to make packaging element decisions. Marketing executives mainly suggested the logistics executives and the food technologists at about the same rate. Similarly, logistics executives suggested collaborating with marketing executives and food technologists. Food technologists who prefer to work with marketing executives numbered twice as many as logistics executives. The findings that the overwhelming majority of executives 
support the idea that all executives should be involved in the packaging decision was very interesting and useful, despite the fact that these executives may all have different perspectives of the different elements of packaging in the food supply chain. Overall, the study proves the need to narrow the gap among managers' perceptions regarding packaging by adopting practices and approaches in an integrated manner.

There are several limitations of this study; the first limitation involves the lack of an investigation into the significance of packaging elements in a part of the food supply chain. This is because the opinions and appreciation of other key players of the food supply chain such as traders and intermediaries, wholesalers, retailers and third part logistics providers and of course, consumers in the design of the packages are of great importance. Another limitation of the study is that it did not examine any differences between different food products and other demographics characteristics such as the size and location of the targeted companies.

A potential future perspective of this study could be the gathering of primary data via questionnaires, which will be filled by consumers of food products. This view would encompass the needs of marketing and logistics managers, food technologists and executives responsible for environmental issues, as well as the consumers of food products. By identifying the significance that all of these stakeholders perceive towards the various elements of the packaging of retail products, manufacturers can take into consideration the elements that are highly appreciated by the key players of the food supply chain.

Author Contributions: A.K. was responsible for the management of the survey. T.F. has organized and run the gathering of primary data. D.F. has prepared the presentation and the analysis of the primary data. All authors have read and agreed to the published version of the manuscript.

Funding: This research received no external funding.

Conflicts of Interest: The authors declare no conflict of interest.

\section{References}

1. NPCS; Board of Food Technologists. 55 Most Profitable Micro, Small, and Medium Scale Food Processing (Processed Food) Projects and Agriculture Based Business Ideas for Startup 2018; NIIR Project Consultancy Services: Delhi, India, 2018; p. 273.

2. Saghir, M. The concept of packaging logistics. In Proceedings of the Second World Conference on POM and 15th Annual POM Conference, Cancun, Mexico, 30 April-3 May 2004.

3. Jönson, G. Packaging Technology for the Logistician, 2nd ed.; Lund University: Lund, Sweden, 2000.

4. Rundh, B. The multi-faceted dimension of packaging: Marketing logistics or marketing tool? Br. Food J. 2005, 107, 670-684. [CrossRef]

5. Cahyorini, A.; Rusfian, E.Z. The effect of packaging design on impulse buying. J. Adm. Sci. Organ. 2011, 18, $11-21$.

6. Underwood, R.L.; Klein, N.M.; Burke, R.R. Packaging communication: Attentional effects of product imagery. J. Prod. Brand Manag. 2001, 10, 403-422. [CrossRef]

7. Underwood, R.L.; Klein, N. Packaging as brand communication: Effects of product pictures on attitude towards the package and brand. J. Mark. Theory Pract. 2002, 10, 58-68. [CrossRef]

8. Limon, Y.; Kahle, L.R.; Orth, U.R. Package design as a communications vehicle in cross cultural value shopping. J. Int. Mark. 2009, 17, 30-57. [CrossRef]

9. Chung, J.E.; Yu, J.P.; Pysarchik, D.T. Cue Utilization to assess food product quality: A comparison of consumers and retailers in India. Int. Rev. Retail Distrib. Consum. Res. 2006, 16, 199-214. [CrossRef]

10. Lofgren, M.; Witell, L. Lano's theory of attractive quality and packaging. Qual. Manag. J. 2005, 12, 7-30. [CrossRef]

11. IPSOS. Most Americans Say That the Design of a Product's Packaging Often Influences Their Purchase Decisions. 2018. Available online: https://www.ipsos.com/en-us/news-polls/Most-Americans-Say-That-theDesign-of-a-Products-Packaging-Often-Influences-Their-Purchase-Decisions (accessed on 3 June 2020). 
12. Loureiro, M.L.; Gracia, A.; Nayga, R.M. Do consumers value nutritional labels? Eur. Rev. Agric. Econ. 2006, 33, 249-268. [CrossRef]

13. Marsh, K.; Bugusu, B. Food Packaging and Its Environmental Impact, Food Technology. 2007, pp. 46-50. Available online: http://www.ift.org/ \{\}/media/Knowledge\%20Center/Science\%20Reports/Scientific\%20Status\% 20Summaries/Editorial/editorial_0407_foodpackaging.pdf (accessed on 3 June 2020).

14. Marsh, K.; Bugusu, B. Food Packaging-Roles, Materials, and Environmental Issues. J. Food Sci. 2007, 72, 40-55. [CrossRef]

15. EPA. Containers and Packaging: Product-Specific Data. 2019. Available online: https://www.epa.gov/ facts-and-figures-about-materials-waste-and-recycling/containers-and-packaging-product-specific-data (accessed on 3 June 2020).

16. Eurostat. Packaging Waste Statistics. 2020. Available online: https://ec.europa.eu/Eurostat/statisticsexplained/index.php/Packaging_waste_statistics\#Waste_generation_by_packaging_material (accessed on 3 June 2020).

17. Rundh, B. Linking Packaging to Marketing: How packaging is influencing the marketing strategy. Br. Food J. 2013, 115, 1547-1563. [CrossRef]

18. Linda, H.; Williams, H.; Olsson, A.; Wikstrom, F. Elucidating the indirect contributions of packaging to sustainable development: A terminology of packaging functions and features. Packag. Technol. Sci. 2016, 29, 225-246. [CrossRef]

19. Singh, P.; Wani, A.; Langowski, H.-W. Packaging Materials, Testing \& Quality Assurance; CRC Press Taylor \& Francis Group: Cleveland, OH, USA, 2017; ISBN 9781466559950.

20. Silayoi, P.; Speece, M. The importance of packaging attributes: A conjoint analysis approach. Eur. J. Mark. 2007, 41, 1495-1517. [CrossRef]

21. Bowersox, D.; Closs, D. Logistical Management: The Integrated Supply Chain Process; McGraw-Hil: New York, NY, USA, 1996.

22. Lambert, D.M.; Stock, J.R.; Ellram, L.M. Fundamentals of Logistics Management; Irwin/McGraw-Hill: Boston, MA, USA, 1998.

23. Louw, A.; Kimber, M. The Power of Packaging, The Customer Equity Company is A Wholly Owned Subsidiary of TNS (UK). 2007. Available online: www.tnsglobal.com/_assets/files/The_power_of_packaging.pdf (accessed on 3 June 2020).

24. Prendergast, G.; Pitt, L. Packaging marketing logistics and the environment are there trade-offs? Int. J. Phys. Distrib. Logist. Manag. 1996, 26, 66-72. [CrossRef]

25. Petljak, K.; Naletina, D.; Bilogrevic, K. Considering ecologically sustainable packaging during decision-making while buying food product. Econ. Agric. 2019, 66, 107-126. [CrossRef]

26. Silayoi, P.; Speece, M. Packaging and purchase decisions: An exploratory study on the impact of involvement level and time pressure. Br. Food J. 2004, 106, 607-628. [CrossRef]

27. Wells, L.E.; Farley, H.; Armstrong, G. A The Importance of Packaging Design for Own-label Food Brands. Int. J. Retail Distrib. Manag. 2007, 35, 677-690. [CrossRef]

28. Keller, K. Building strong brands in a modern marketing communications environment. J. Mark. Commun. 2009, 15, 139-155. [CrossRef]

29. Butkeviciene, V.J.; Stravinskiene, A. Rutelione Impact of consumer package communication on consumer decision making process. Eng. Econ. 2008, 56, 57-65.

30. Vila, N.; Ampuero, O. The role of packaging in positioning an orange juice. J. Food Prod. Mark. 2007, 13, 21-48. [CrossRef]

31. Simms, C.; Trott, P. Packaging development: A conceptual framework for identifying new product opportunities. Mark. Theory 2010, 10, 397-415. [CrossRef]

32. Appendini, P.; Hotchkiss, J.H. Review of Antimicrobial Food Packaging. Innov. Food Sci. Emerg. Technol. 2002, 3, 113-126. [CrossRef]

33. Sorrentino, A.; Gorrasi, G.; Vittoria, V. Potential Perspectives of Bio-Nanocomposites for Food Packaging Applications. Trends Food Sci. Technol. 2007, 18, 84-95. [CrossRef]

34. Suchard, H.T.; Polonski, M.J. A theory of environment buyer behavior and its validity: The environmental action-behaviour model. AMA Summer Educ. Conf. Proc. Am. Mark. Assoc. 1991, 2, 187-201.

35. Teisl, M.F.; Roe, B.; Hicks, R.L. Can Eco-Labels Tune a Market? Evidence from Dolphin-Safe Labeling. J. Environ. Econ. Manag. 2002, 43, 339-359. [CrossRef] 
36. Leire, C.; Thidell, A. Product-related environmental information to guide consumer purchases-A review and analysis of research on perceptions, understanding and use among Nordic consumers. J. Clean. Prod. 2005, 13, 1061-1070. [CrossRef]

37. Lee, S.; Rajagopalan, P. Building energy efficiency labeling programme in Singapore. Energy Policy 2008, 36, 3982-3992. [CrossRef]

38. European Parliament. Circular Economy Package, four Legislative Proposals on Waste. 2016. Available online: https://www.europarl.europa.eu/news/en/headlines/society/20170120STO59356/thecircular-economy-package-new-eu-targets-for-recycling (accessed on 3 June 2020).

39. European Commission. Environment: Higher Recycling Targets to Drive Transition to a Circular Economy with New Jobs and Sustainable Growth. 2014. Available online: https://www.rsupply.com/en/home-en/9news/29-eu-defines-70-recycling-target-for-2030-to-promote-circular-economy (accessed on 3 June 2020).

40. European Commission. Food Information to Consumers-Legislation. 2014. Available online: https: //ec.europa.eu/food/safety/labelling_nutrition/labelling_legislation_en (accessed on 3 June 2020).

41. Prendergast, G.; Marr, N. Perceptions of generic products: A macro and micro view. J. Prod. Brand Manag. 1997, 6, 93-108. [CrossRef]

42. Rettie, R.; Brewer, C. The verbal and visual components of package design. J. Prod. Brand Manag. $2000,9$. [CrossRef]

43. Estiri, M.; Hasangholipour, T.; Yazdani, H.; Nejad, H.; Rayej, H. Food Products Consumer Behaviors: The Role of Packaging Elements. J. Appl. Sci. 2010, 10, 535-543. [CrossRef]

44. Guillard, V.; Gaucel, S.; Fornaciari, C.; Angellier-Coussy, H.; Buche, P.; Gontard, N. The Next Generation of Sustainable Food Packaging to Preserve Our Environment in a Circular Economy Context. Front. Nutr. 2018, 5, 121. [CrossRef]

45. Cabot, I.; Luque, A.; de las Heras, A.; Aguayo, F. Correction: Aspects of sustainability and design engineering for the production of interconnected smart food packaging. PLoS ONE 2019, 14, e0218337. [CrossRef] [PubMed]

46. Molina-Besch, K.; Wikström, F.; Williams, H. The environmental impact of packaging in food supply chains-does life cycle assessment of food provide the full picture? Int. J. Life Cycle Assess. 2019, 24, 37-50. [CrossRef]

47. Wikström, F.; Williams, H. Potential environmental gains from reducing food losses through development of new packaging-A life cycle model. Packag. Technol. Sci. 2010, 23, 403-411. [CrossRef]

48. Paine, F. Packing and the Environment; Wiley Online Library: Hoboken, NJ, USA, 1992.

49. Regattieri, A.; Santarelli, G. The Important Role of Packaging in Operations Management; Intechopen: London, UK, 2012. [CrossRef]

50. Rundh, B. Packaging design: Creating competitive advantage with product packaging. Br. Food J. 2009, 111, 988-1002. [CrossRef]

51. Konstantoglou, A.; Kokmotos, E.; Folinas, D.; Fotiadis, T. Significance of packaging elements from a marketing and logistics points of view. In Proceedings of the 4th International Conference on Contemporary Marketing Issues, Heraklion, Greece, 22-24 June 2016.

52. Konstantoglou, A.; Folinas, D.; Fotiadis, T.; Damalis, V.; Voulgarakis, N. The influence of consumer habits and behaviors in the appreciation of labeling and packaging elements: A study in the food supply chain. In Proceedings of the 5th International Conference on Contemporary Marketing Issues, Thessaloniki, Greece, 21-23 June 2017.

53. Konstantoglou, A.; Folinas, D.; Fotiadis, T.; Rallis, S.L.; Chatzithomas, L.; Gasteratos, A. Development of a holistic framework for the key packaging elements of agri-food products. J. Eng. Sci. Technol. Rev. 2020, 13, 23-31. [CrossRef]

54. PWC. Food and Beverage Industry/Annual Sectorial Report. 2018. Available online: https://www.pwc.com/gr/ en/publications/greek-thought-leadership/the-food\%20\&\%20beverage-sector-in-greece(en).pdf (accessed on 3 June 2020).

55. Hellström, T. Dimensions of environmentally sustainable innovation: The structure of eco-innovation concepts. Sustain. Dev. 2006, 15, 148-159. [CrossRef]

(C) 2020 by the authors. Licensee MDPI, Basel, Switzerland. This article is an open access article distributed under the terms and conditions of the Creative Commons Attribution (CC BY) license (http://creativecommons.org/licenses/by/4.0/). 